\title{
Radiation Pollution in Cancer and other Diseases Using some Immunological and Clinical Parameters Weam Saad Al-Hamadany ${ }^{1}$, Dhuha S. Saleh ${ }^{2}$, Muthana A. Shanshal ${ }^{3}$
}

1- Department of Microbiology/College of Veterinary Medicine/University of Baghdad 2-Department of Biology/College of Science/University of Baghdad ,3-Department of Chemistry/College of Science/University of Baghdad

\begin{abstract}
Summary
There was a noticeable increase in cancers, congenital malformations, spontaneous abortion and other cases among Iraqi population after both Gulf Wars I and II, the present study aimed to the detection and determination of internal radiation pollution with Depleted Uranium (DU), and investigate the effects of this type of radiation exposure on some immunological parameters for the first time in Iraq. A total of 88 blood samples were collected from 45 patients and 43 healthy persons during 2009-2010; from the outpatients of the Institute and Hospital of Radiotherapy and Nuclear Medicine and Al-Kadhymia Teaching Hospital in Baghdad. Results: 1. Contaminated persons with DU were 48 persons $(54.5 \%)$ from total 88 persons. 2. The places (Al-Taji, Abu-Graib, Al-Hurriyah, New Baghdad and AlSader town) recorded $44.7 \%$ of contaminated persons. 3. Effects of internal contamination with DU; chronic radiation exposure; influenced by the dose and personal susceptibility, thus it caused significant decrease in Eosinophils $\%$ and Lymphocytes $\%, \mathrm{Hb} \%, \mathrm{NBT}+\%$ and most of IFN- $\gamma$ levels, while there was some elevation in Basophiles\%. 4. IL-2 levels did not affected by chronic exposure by DU. But it was affected by acute exposure to radiation since its levels elevated significantly in radiation occupationals blood.Conclusions: Radiation pollution as internal contamination with $U$ and DU is a public health problem. It might be the predisposing factor for the cases under focus since it caused immunosuppression by affecting immune cells in number or function comparing with the non-contaminated.
\end{abstract}

*Aspirated from PhD thesis for the first researcher Dr.Weam Saad Al-Hamadany. (Email: akweam@yahoo.com)

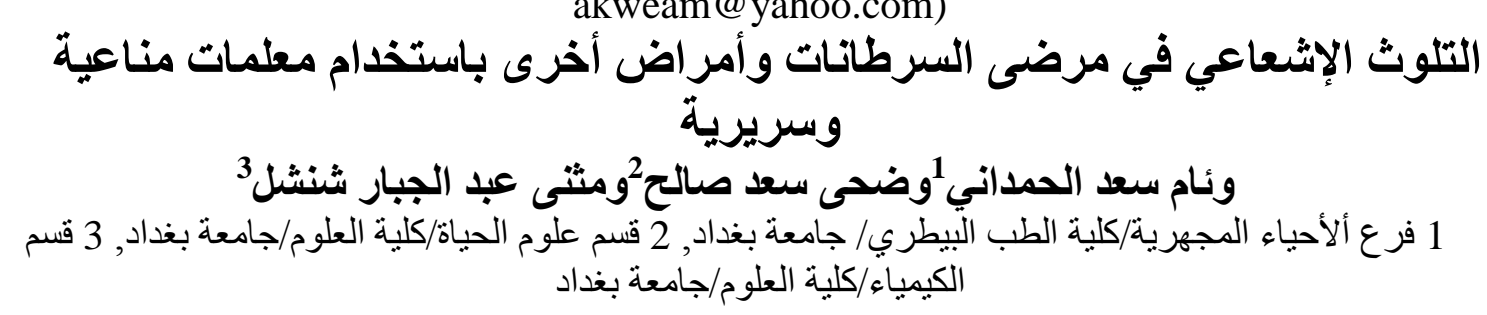

\section{الخلاصة}

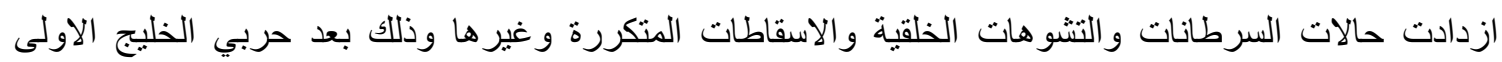

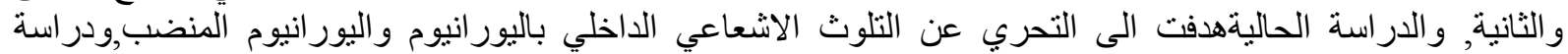

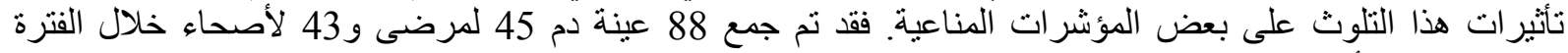

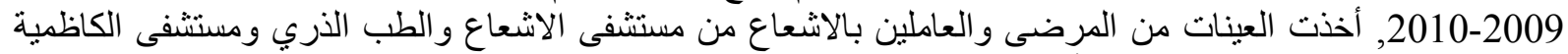

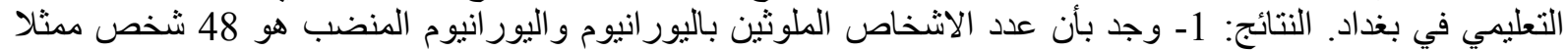

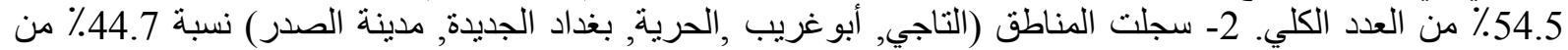

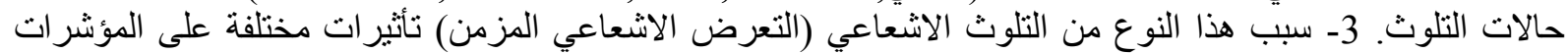

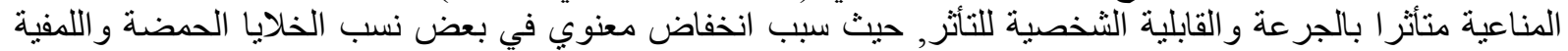
ونسبة خضاب الدم ونسبة الخلايا الموجبة لاختز ال (NBT)

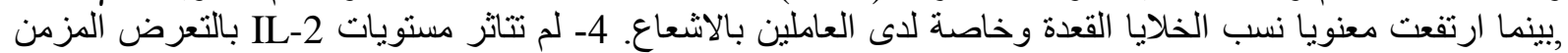

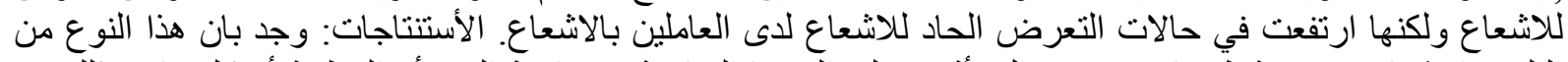

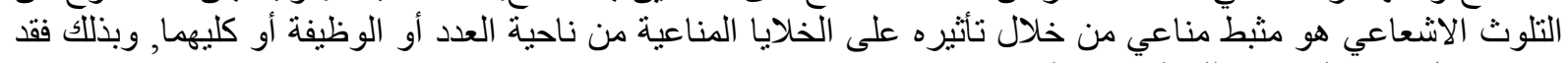
يكون عامل محفز لحدوث تللك الحالات المرضية. 


\section{Introduction}

Ionizing Radiation is one of the most dangerous types of environmental pollution since it cannot be seen, smelled or tasted; also it can be detected only by special instruments and equipments and requires specialized expertise technicians (1). In Iraq, Depleted Uranium (DU) was and still an environmental pollution problem since its levels raised after both Gulf wars I and II, and the contaminated places have not been limited or isolated to stop and avoid the spreading of this radioactive contamination (2). Depleted Uranium is an alpha particles radiation emitter; its importance came from its radioactivity and cytotoxicity. It is able to precipitate and accumulate inside human body when there is an internal exposure and acts as a source of radiation until excretion by urine which may take years. What is worse than that; DU contamination has a latent period until the appearance of clinical signs and that period usually takes (1-5 years) depending on dose of exposure and personal susceptibility. Depleted Uranium effects in human body are so many, the immune system is one of its targets especially cell mediated immunity (CMI) since radiation mostly hits Innate Immunity components (3). There was a noticeable increase in the cases of cancers, congenital malformations and other cases in the last decade among Iraqi population (4). So the present study aimed to: 1 .Detection and determination of internal radiation pollution with DU, and identify the most affected patients and healthy peoples resident in some Iraqi areas. 2. Investigate the relationship and effects of this type of radiation exposure and some immunological aspects of the immune system health and function in some healthy and patients individuals randomly chosen.

Depleted Uranium and Human Health, the intact skin is a good barrier against external contamination and shield $\alpha$ radiation emitted by DU. Internal contamination occurs by three means: Inhalation, Ingestion and Contact (skin and wounds) (5). Uranium is always a contaminant since most of its compounds are toxic. Kidneys are the main site of damage due to its chemical toxicity, Lungs, CNS, Liver, Pancreas and Spleen can be damaged by DU accumulation, also series reproductive problems results due to DU exposure (e.g. Congenital malformations)(6). On the cellular and molecular levels; when the metabolic functions of the contaminated human body failed to excrete DU, each $\alpha$-particle emitted, hits 7 cells in spherical directions and in a continuous manner. If the damage in DNA cannot be repaired; the affected cells shall die or convert to cancerous cells (tumor formation) (7 and 8).

Monitoring: Geiger counter for the external contamination is usually used, while for internal contamination Analysis of daily urine excretion; Chest DU measurement and Blood analysis using the usual parameters for radiation exposure detection (9). Treatment: administration of the drug Catechol-3,6-bis (methyleiminodiacetic acid) (CBMIDA) and Sodium bicarbonate intravenously to increase excretion of DU by urine. Dialysis sometimes is necessary (10).

\section{Materials and Methods}

Patients Groups and Controls: A total of 88 blood samples were collected. Including 45 patients and 43 healthy peoples; obtained from Iraqi community. All the related informations were documented in the data forms. The followings are the groups of the study:

I. Group one (G1): Included 15 blood samples taken from untreated cancer patients newly identified in the Institute and Hospital of Radiotherapy and Nuclear medicine in Baghdad, (no medication taken before especially radiotherapy and involved any cancer type).

II. Group two (G2): Included 15 blood samples taken from cancer patients during their periodic chemical therapy treatment (before the administration of chemotherapy, not more than two doses and no radiotherapy).

III. Group three (G3): Included 15 blood samples taken from Gynecology department outpatient women in the consultative polyclinic of Al-Kadhymia Teaching Hospital in Baghdad. These cases involved (Congenital malformation, Spontaneous abortion and Molar pregnancy). 


\section{Proceeding of the Eleventh Veterinary Scientific Conference, 2012; 33-40}

IV. Group four (G4): Included 14 blood samples taken from the Institute and hospital of Radiotherapy and Nuclear Medicine occupationals, nurses, technicians, doctors, and employees, they were healthy with no clinical signs of any disease.

V. Group five (G5): Included 15 blood samples taken from peoples who were residents of places identified or suspected of radiation pollution (involved peoples who resident these places at the time of study or before that). The contaminated places were dependent according to the Iraqi Ministry of Environment and the United Nations Environmental Program (UNEP, 2007) (11).

VI. Group six (G6): Included 14 blood samples taken from healthy volunteers whose resident places away from radiation pollution and were not exposed to ionizing radiation during their jobs.

Depleted Uranium Estimation: Since the most common type of radiation exposure in our country is DU contamination; in this study we searched for Ionizing Radiation Pollution with DU by the method of Solid State Nuclear Track Detectors (SSNTDs) using CR-39 polymer, this detection was applied on all blood samples that were collected (4). The obtained values were in $\operatorname{ppm}(12,13)$.

Immunological and Hematological Parameters: The parameters that were used to determine the effects of radiation on human immune system were:

1. Total and Differential W.B.Cs Count: The total count tests were done using Neubauer Haemocytometer chamber and freshly collected heparinized blood with total WBCs diluting fluid as in recommended by (14). Also Hepanized blood samples were used to differential count by preparing thin smears stained with Leishman's stain and examined under oil immersion, counting (100) white cells, and estimating each type percentage (15).

2. Hemoglobin Concentration Measurement: Haemoglobincyanide (HiCN) method was used via the dilution of heparinized blood with Drabkin's reagent. This diluting solution contains potassium cyanide $(\mathrm{KCN})$ and forming $\mathrm{HiCN}$. The absorbance was measured using Digital photoelectric colorimeter and concentrations were in $\mathrm{g} / \mathrm{dl}$, whereas $\mathrm{dl}=100 \mathrm{ml}$ of blood $(16,14)$.

3. Nitro-blue Tetrazolium (NBT) Test: This test was used for neutrophils phagocytic activity evaluation. It involves the detection of respiratory oxidative burst activity in neutrophils via the ability to reduce NBT dye and deposit it as dark blue crystals (Formazan particles) (17).

4. Human Gamma Interferon (IFN- $\gamma$ ): The ELISA using the Kit of Enzyme Immune Assay EIA was used for invitro determination of IFN- $\gamma$ concentrations in human serum. Bioelisa set was used for this test.

5. Human Interleukin (IL-2) Kit: The ELISA using the kit of Enzyme Immune Assay (EIA was used for invitro determination of IL-2 concentrations in human serum. Bioelisa set was used for this test.

Statistical Analysis: All results of all the six groups were statistically analyzed using mean calculations (M) and standard Error (SE) using Statistical Analysis System SAS (2000). Each group results were compared with the other groups results using student t-test to find the significance of probability level $(\mathrm{P})$ of increase or decrease for all of the studied parameters, the level $(\mathrm{p}<0.05)$ was dependent as the significance level $(18)$.

\section{Results}

The recorded contaminated persons with DU were 48 cases $(54.5 \%)$ from the total 88 cases in all groups; including controls their values increased significantly comparing with control group who were normal, table (1). The dependant normal U or DU value in human blood was equal or bellow (0.115 p.p.m) according to (19). 
Proceeding of the Eleventh Veterinary Scientific Conference, 2012; 33-40

Table (1): Depleted Uranium concentrations in blood samples for all groups as compared with control group

\begin{tabular}{|c|c|c|c|c|}
\hline No. & Group & $\begin{array}{c}\text { No. of } \\
\text { Cases }\end{array}$ & $\begin{array}{c}\text { DU M } \pm \text { SE } \\
\text { p.p.m. }\end{array}$ & Range \\
\hline 1 & G6 & 14 & $0.11 \pm$ & 0.009 \\
& & 74 & $0.21 \pm$ & $0.432)$ \\
\hline 2 & All other groups & & $0.01^{*}$ & $0.800)$ \\
& $\begin{array}{c}\text { (G1,G2,G3,G4\& } \\
\text { G5) }\end{array}$ & & & \\
\hline
\end{tabular}

*:Significant difference at level $(\mathbf{p}<0.05)$.

$(\mathrm{M} \pm \mathrm{SE})$ : Mean \pm Standard error.

The Tables (2) shows hematological results and the Table (3) shows the immunological results obtained for all groups. Total W.B.C.s and Neutrophils Counts Results for DU contaminated persons were within middle average with some variations according to (14), no significant increase or decrease recorded in Neutrophils counts. But Total W.B.Cs results recorded significant increase $(\mathrm{p}<0.05)$ in $\mathrm{G} 1, \mathrm{G} 2$ and G4 comparing with G6, Eosinophils percentages in DU contaminated persons in all groups were mostly decreased. A number of 30 persons $(62.5 \%)$ had diminished percentages. Basophils count results were the only results recorded significant difference $(\mathrm{p}<0.05)$ and increased comparing with control G6; concerning all differential and total W.B.C.s counts for all groups. Also several cases among laboratory technicians of radiotherapy administration; in the Institute and Hospital of Radiotherapy and Nuclear Medicine/Baghdad; recorded with elevated Basophiles percentages even they were not DU contaminated. Monocytes counts were all within normal range. Lymphocytes count for DU contaminated persons recorded 15 cases (31.2\%) from the total 48 with abnormal lymphocytes percentages (increased or decreased compared with the normal range). Hemoglobin Results, all groups showed a significant decrease with a difference ( $\mathrm{p}<0.05)$ comparing with G6. And concerning DU contaminated persons; there were 21 cases (43.8\%) recorded with diminished $\mathrm{Hb} \%$ values among the total 48. Test of NBT for Neutrophils phagocytic Activity showed significant decrease in the levels obtained for all groups, Picture (1). And there were 23 cases (47.9\%) recorded with diminished positive neutrophils percentages among DU exposed, (Picture 1). Despite of the fact that; no significant difference was obtained for all groups in IFN- $\gamma$ levels. But there were 45 (93.8\%) cases from the total 48 who had decreased values. While there was a significant increase in IL-2 levels found in occupationals samples (G4 group). Other groups had normal levels.

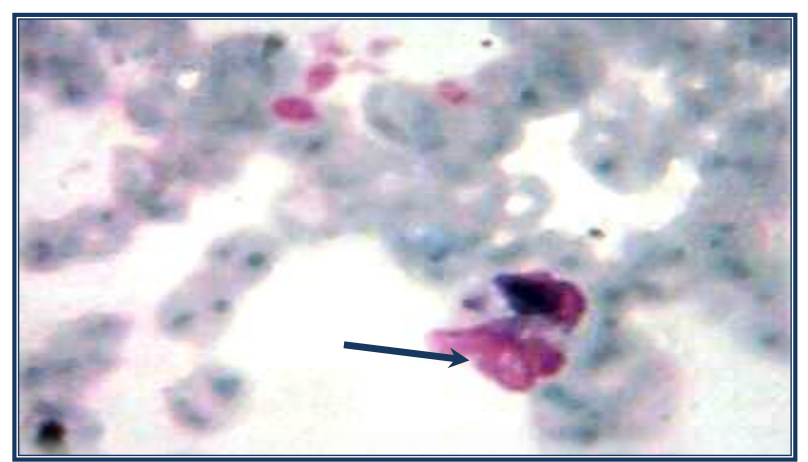

Picture (1): Positive Neutrophil ofcontrol blood sample for NBT test, Arrow pointing to Formazan Crystals. 
Proceeding of the Eleventh Veterinary Scientific Conference, 2012; 33-40

Table (2): Hematological Results obtained for all groups.

\begin{tabular}{|c|c|c|c|c|c|c|c|}
\hline \multirow{2}{*}{$\begin{array}{c}\text { Grou } \\
p\end{array}$} & \multirow{2}{*}{$\begin{array}{c}\text { Total } \\
\text { W.B.Cs }\end{array}$} & \multicolumn{5}{|c|}{ Differential W.B.Cs } & \multirow[t]{2}{*}{$\mathrm{Hb} \%$} \\
\hline & & Neu. & Baso. & Eosin. & Mono. & Lymph & \\
\hline G1 & $7600 \pm 941.3^{*}$ & $\begin{array}{l}66.40 \pm \\
3.4\end{array}$ & $\begin{array}{r}0.13 \pm \\
0.09\end{array}$ & $\begin{array}{r}1.13 \pm \\
0.09\end{array}$ & $\begin{array}{lr}5.1 & \pm \\
& 0.73\end{array}$ & $\begin{array}{l}27.9 \pm \\
3.1\end{array}$ & $\begin{array}{l}11.4 \pm 0.69 \\
*\end{array}$ \\
\hline G2 & $\begin{array}{l}7060 \pm 629.04 \\
*\end{array}$ & $\begin{array}{l}66.13 \pm \\
2.4\end{array}$ & $\begin{array}{lr}0.2 & \pm \\
& 0.1^{*}\end{array}$ & $\begin{array}{r}1.27 \pm \\
0.3^{*}\end{array}$ & $\begin{array}{lr}5.5 & \pm \\
& 0.42\end{array}$ & $\begin{array}{l}26.7 \pm \\
2.1\end{array}$ & $\begin{array}{l}12.8 \pm 0.63 \\
*\end{array}$ \\
\hline G3 & $5620 \pm 435.7$ & $\begin{array}{l}66.00 \pm \\
1.1\end{array}$ & $\begin{array}{r}0.07 \pm \\
0.07\end{array}$ & $\begin{array}{r}1.2 \pm \\
0.31^{*}\end{array}$ & $\begin{array}{lr}3.5 & \pm \\
& 0.43\end{array}$ & $\begin{array}{l}29.2 \pm \\
0.8\end{array}$ & $\begin{array}{l}11.8 \pm 0.4 \\
*\end{array}$ \\
\hline G4 & $\begin{array}{l}6492.9 \pm 536 . \\
*\end{array}$ & $\begin{array}{l}62.86 \pm \\
1.2\end{array}$ & $\begin{array}{lr}0.5 & \pm \\
& 0.2^{*}\end{array}$ & $\begin{array}{r}1.71 \pm \\
0.45\end{array}$ & $\begin{array}{lr}5.2 & \pm \\
& 0.45\end{array}$ & $\begin{array}{l}29.7 \pm \\
0.8\end{array}$ & $\begin{array}{l}13.4 \pm 0.5 \\
*\end{array}$ \\
\hline G5 & $\begin{array}{l}5646.7 \pm 587 . \\
6\end{array}$ & $\begin{array}{l}61.93 \pm \\
1.2\end{array}$ & $\begin{array}{r}0.3 \pm \\
0.15^{*}\end{array}$ & $\begin{array}{lr}2.5 & \pm \\
& 0.38\end{array}$ & $5.47 \pm 0.6$ & $\begin{array}{l}29.8 \pm \\
1.3\end{array}$ & $\begin{array}{l}13.4 \pm 0.4 \\
*\end{array}$ \\
\hline G6 & $\begin{array}{l}5326.7 \pm 553 . \\
1\end{array}$ & $\begin{array}{l}64.53 \pm \\
1.5\end{array}$ & $\begin{array}{lr}0.27 & \pm \\
& 0.1\end{array}$ & $2.8 \pm 0.5$ & $\begin{array}{lr}4.67 & \pm \\
& 0.6\end{array}$ & $\begin{array}{l}27.7 \pm \\
1.4\end{array}$ & $\begin{array}{l}13.2 \\
0.53\end{array}$ \\
\hline
\end{tabular}

*:Significant difference at level $(\mathrm{p}<0.05)$.

$(\mathrm{M} \pm \mathrm{SE}):$ Mean \pm Standard error

Table (3): Immunological Results obtained for all groups

\begin{tabular}{|r|c|c|c|}
\hline Group & NBT & IFN- $\gamma$ & IL-2 \\
\hline G1 & $55.8 \pm 4.57^{*}$ & $0.293 \pm 0.04$ & $427.9 \pm 63.7$ \\
\hline G2 & $59.1 \pm 3.67 *$ & $0.266 \pm 0.01$ & $586.6 \pm 240.1$ \\
\hline G3 & $57.9 \pm 2.99^{*}$ & $0.260 \pm 0.01$ & $349.5 \pm 13.2$ \\
\hline G4 & $54.6 \pm 2.72 *$ & $0.254 \pm 0.01$ & $3175.5 \pm 994.9^{*}$ \\
\hline G5 & $62.0 \pm 3.57^{*}$ & $0.278 \pm 0.01$ & $802.4 \pm 369.6$ \\
\hline G6 & $67.1 \pm 2.49$ & $0.264 \pm 0.008$ & $353.8 \pm 12.03$ \\
\hline
\end{tabular}

*:Significant difference at level $(p<0.05) . \quad(M \pm S E)$ : Mean \pm Standard error

\section{Discussion}

Contamination with DU found to be a public health problem since 54.5\%; from the total 88 persons involved in this research; were contaminated internally with DU. The places (AlTaji, Abu-Graib, Al-Hurriyah, New Baghdad and Al-Sader town) had 44.7\% of contaminated persons residences.

The total W.B.Cs and Neutrophils counts results for all groups influenced by the case type; especially in cancers; and radiation exposure whether chronic (DU contamination) or acute (radiation occupationals). Neutrophils counts suggested that peripheral Neutrophils were not affected by radiation exposure with DU in their relative numbers; the same opinion was documented by (20). Also poor supplies for radiation occupationals played role in elevation the numbers of contaminated persons in G4 (21). The decrease in Eosinophil percentages in DU contaminated persons can be attributed to DU which affects their CMI activity (21). The significant increase in Basophile numbers was in agreement with (22), he found that Basophile numbers were increased in Rats blood after irradiation with DU. The cases of elevated Basophiles among laboratory technicians can be attributed to the acute radiation exposure during work as (22).

Normal Monocytes count due to the fact that Monocytes are the most radio-resistant cells whether they were in blood or tissues and usually their levels in peripheral blood stay near normal limits and their function stay effective (23). Lymphocytes are the most sensitive immune cells to radiation, since they are dividing continuously, which makes them a target for radiation which leads to early apoptosis (24). The result of decreased Lymphocytes 


\section{Proceeding of the Eleventh Veterinary Scientific Conference, 2012; 33-40}

counts; that obtained for DU contaminated persons; gave an additional prove concerning DU as a predisposing factor for cancer and the other cases in the present study. That is consistent with the opinion of (21). The genotoxic effects of DU may exceed the threshold and cause somatic mutations and let these cells to divide in uncontrolled manner (25). That was the explanation for some recorded values which increased rather than decreased. The present study concentrated on lymphocytes relative percentages in relation to ionizing radiation caused by DU. Since there were no former local study that estimated the relation between lymphocytes numbers and DU concentration; our study set the ground for more investigations by serial periodic observation for lymphocytes relative numbers in DU contaminated persons to give an obvious view about lymphocytes number behavior along with DU contamination existence internally.

The results of Hemoglobin suggested that DU exposure increased the cases severity through increasing anemia cases number. These findings were in agreement with those of (26). Who found that contaminated persons with DU (citizens and occupationals) had decreased $\mathrm{Hb} \%$ levels. While (22), found that contaminated persons with DU; as well the irradiated rats with DU; had decreased hemoglobin values due to R.B.C.s destruction. Many cases of chronic anemia recorded among the technicians of the Institute and Hospital of Radiotherapy and Nuclear Medicine; even if they were not DU contaminated. But this may due to their precursors' damage as stated by (27).

Concerning NBT Test Results; DU affected Neutrophils phagocytic Activity which suppressed significantly. The authors (28) stated that phagocytic cells in peripheral blood can be influenced by any factor that affect their metabolism or function like radiation. They used NBT reduction capacity test to investigate that. Locally, this study was the first research that investigated the effects of $\mathrm{U}$ or DU on neutrophils function and activity by using NBT reduction test. In Iraq; no study before took care with radiation and NBT test according to our references. From the results internal exposure to DU was able to cause neutrophils activity suppression with no sharp decrease in their relative numbers.

The levels of IFN- $\gamma$ suggested that DU had a negative impact on IFN- $\gamma$ levels in DU contaminated person's blood. This lymphokine; is produced by T-cells (Th1, Tc, NK); represents the effective arm of CMI; because it is able to enhance MHC I and MHC II, and inhibits Th2 proliferation (27). From our findings, the suppression in CMI (that usually results after radiation exposure) may be corroborated by diminished IFN- $\gamma$ levels due to radiation effects on lymphocytes that affecting cytokines production and immune system regulation (3). The authors (29) stated that radiation is one of the immunosuppressant agents since it interferes with lymphocytes activity and function. These finding are also supported by (30); they investigated IFN- $\gamma$ administration for Chernobyl survivors to improve their immune system after suppression due to radiation exposure. Also the references (31) and (32) stated that IFN- $\gamma$ levels increased in women with recurrent spontaneous abortion in G3 group; but they were decreased; despite this group contained 7 cases with spontaneous abortion from a total 15. These findings are also in compatibility with those of Lymphocytes count in this study.

The significant increase in the IL-2 levels in G4 occupationals can due to acute radiation exposure effects during their work; with the considerations of dose, duration and personal susceptibility. Also the present outcomes suggested that IL-2 levels influenced by the type of radiation exposure whether acute or chronic. Low doses of radiation can cause elevation in the levels of IL-2 as stated by (33).

Conclusion: Depleted Uranium pollution is a public health problem in Iraq, it was immunosuppress or affected the immune cells either by number or function or both resulting of diminished immune activity hence contaminated patients with DU were unable to generate normal immune response.

\section{References}




\section{Proceeding of the Eleventh Veterinary Scientific Conference, 2012; 33-40}

1. UNEP (2007). Technical Report on Capacity-building for the Assessment of Depleted Uranium in Iraq. Final Report, November. Geneva.

2. IAEA (2010). Radiological Conditions in Selected Areas of Southern Iraq with residues of Depleted Uranium: Report by an international group of experts. Vienna.

3. Briner, W. (2010). The Toxicity of Depleted Uranium. Int. j. environ. Res. Public health; January; 7 (1): 303-313.

4. Al-Azzawi, S.N. (2006). Depleted Uranium Radioactive contamination in Iraq: An Overview. Global Res. August 3-6. $3^{\text {rd }}$ ICBUW International Conference Hiroshima.

5. Parrish, R.; and et al. (2008). Depleted Uranium Contamination by Inhalation Exposure After Approximately 20 Years: Implications for Human Health Assessment. J. Sci. Total Environ. Feb1; 390(1): 58-68.

6. Bleise, A.; Danesi, P.; and Burkat, W. (2003). Properties, Use and Health Effects of Depleted Uranium (DU): a General Overview. J. Environ. Radioact; 64(2-3): 93-112.

7. International Institute of Cancer for Public Health. (2005). Update on Depleted Uranium and Gulf War Syndrome. Pt. 1, 23. Apr. 2005.

8. Sztajnkrycer, M.; and Otten, E. (2004). Chemical and Radiological Toxicity of Depleted Uranium. J. Military Medicine 2004 Feb. 27; 67(4): 277-96.

9. McCunney, R.; Masse, f.; and Galanek, M. (1999). Occupational Ingestion of p-32: the Value of monitoring Techniques to Determine Dose: A Case Report. J. Occup-EnvironMed. Oct; 41 (10): 878-83.

10. Fukuda, S.; Ikeda, M.; Nakamura, M. ;Yan, X.; Xie, Y. (2006a). Effects of CBMIDA Administered Orally and Intrapertoneally on the Removal of Depleted Uranium in Rats. $16^{\text {th }}$ International Conference on Chelators (ICOC). Oct 25-31. Limassol, Cyprus.

11. Ministry of Environment (2009a). Radiation Protection Center. Document No. 3468. Dated: Sep.8.2009. Iraq.

12. Tawfiq. N. F. (1996). Comparison Study Some Organic and Inorganic Nuclear Track Detectors and their Applications in Environment. Ph.D thesis. Dep. of physics. Coll. Of Education. Uni. Al-Mustansiriyah. Iraq.

13. Tawfiq, N. F.(2011).Uranium Concentration Measurements of Human Blood Samples Using CR-39. International Conference of Salahaddin University- Erbil. October 17-21.

14. Mckenzie, S. B. (2004). Clinical Laboratory Hematology. Pearson Education, Inc. USA.

15. Theml, H.; Diem, H.; and Haferlach, T. (2004). Color Atlas of Hematology. $2^{\text {nd }}$ ed. Tieme Verlag pub. Germany.

16. Lewis, S. m.; Bain, B. J; Bates, I. (2006) Dacie and Lewis: Practical Hematology. $10^{\text {th }}$ ed. Elsevier Ltd. Churchill Livingstone. Germany.

17. Edgar, J. D. (2006). Immunology: Master Medicine. $1^{\text {st }}$ ed. Elsevier Churchill Livingstone Pub. China.

18. Statistical Analysis System SAS (2000). SAS/Stat user guide for personal computer. Release 6.12 SAS Institute. Inc. Cary. N.C. USA.

19. International Commission on Radiological Protection (ICRP) (2006). Uranium ( $Z=92$ ). Consultation Draft. Jan.16.2006.

20. Monleau, M.; and et al. (2006). Genotoxic and inflammatory Effects of Depleted Uranium Particles Inhaled by rats. J. Toxical. Sci. Jan; 89 (1): 287-295.

21. Al-Tememy, L. T. (2007). Uranium concentration Measurements of Human blood samples using CR-39. MSc. Thesis. Department of Physics. College of Science. Al-Nahrain University. Iraq.

22. Al-Zubaidi, L.A. (2003). A Study of the Effect of pollution with Depleted Uranium on certain blood parameters. Msc Thesis. Dep.of Biology. Baghdad University.

23. Buescher, E.; and Gallin, J. (1984). Radiation effects on Cultured Human Monocytes and on monocytes-drived Macrophages. J. Blood. Jan; 63: 1402-1407. 
24. Belloni, P.; mschini, R; Czene, S.; Harms-Ringdahl, M.; and Palitti, F. (2005). Studies on Radiation-Induced Apoptosis in Go Human lymphocytes. Int-J. radiat-Biol.Aug; 81(8): 587-99.

25. Howe, O.; and et al. (2005). Cell Death Mechanisms Associated with G2 Radio Sensitivity in Patients with Prostate Cancer and Benign Prostatic Hyperplasia. Radiat-Res. Nov; 164(5): 627-34.

26. Milacic S; and Simic J. (2009). Identification of Health Risks in Workers Staying and Working on the terrains contaminated with depleted uranium. J. Radiat. Res. May; 50(3): 213-22.

27. Delves, P. J.; Martin, S. J.; Burton, D. R.; and Roitt, I. M.; (2006). Roitt's Essential Immunology. $11^{\text {th }}$ ed. Blackwell publishing Ltd. USA.

28. Novellino, P; Trejo, Y.; Beviacqua, M.; Bordenave, R.; and Rumi, L. (1999). Effect of Culture Supernatants from Two Cancer Cell Lines on Healthy Donors' Monocytes. J. Allergol-Immunopathol-(Madr). Jul-Aug; 27 (4): 195-9.

29. Tizard, I. R.(2009). Veterinary Immunology: An Introduction. $8^{\text {th }}$ ed. Saunders Elsevier Inc. Pub. USA.

30. Peter, R.; and et al. (1999). Interferon Gamma in Survivors of the Chernobyl Power Plant Accident: New Therapeutic Option for Radiation-induced Fibrosis, Int-j-radiat-Oncol-Biolphys. Aug 1; 45 (1): 147-52.

31. Al-Obaidi, A. and Habib, M. (2009). IFN- $\gamma$ Versus IL-10 in Situ Expression in Recurrent Spontaneous Abortion. IRAQI J Med Sci., Vol.7 (1): 21-29.

32. Mohymen, N.; and Amal, H. (2008). Detection of IL-8, IL-10 and IFN- $\gamma$ mRNA in Trophoblast Tissues of Recurrent Spontaneous Abortion using in situ Hyperdization. IRAQI J. Med Sci.; Vol. 6(1): 121-127.

33. Cheda, A; Nowosielska, E; Wrembel-Wargocka, J; and Janiak, M. (2008). Production of Cytokines by Peritoneal Macrophages and Splenocytes after Exposures of Mice to Low Doses of X-rays. J-Rad. And Env. Biophys., Vol. 47 No. 2. Apr. 275-283. 